\title{
Analisis Pengaruh Profitabilitas Dan Leverage Terhadap
}

Kebijakan Dividen

Bambang Widjanarko Susilo ${ }^{1}$

Riyono $^{2}$

Ninik Dwi Atmini ${ }^{3}$

Manajemen, Institut Teknologi dan Bisnis Semarang, Semarang, Indonesia

\section{Info Artikel}

\section{Sejarah Artikel:}

Diterima : 9 juli 2020

Disetujui : 10 juli 2020

Dipublikasikan : 14 juli 2020

\section{Keywords:}

Profitabilitas, Leverage, Dan

Kebijakan Dividen

\begin{abstract}
Abstrak
Tujuan penelitian ini untuk menganalisis pengaruh profitabilitas dan leverage terhadap kebijkan dividen. Sampel penelitian ini adalah perusahaan manufaktur yang terdaftar pada di Bursa Efek Indonesia (BEI) tahun 2015-2018. Teknik pengambilan sampel dengan menggunakan metode purposive sampling. Jumlah sampel dalam penelitian ini sebanyak 27 perusahaan dengan 108 data selama empat tahun. Setelah melakukan uji normalitas, terdapat sejumlah beberapa data yang dihilangkan, sehingga data yang digunakan dalam penelitian menjadi 92 data. Teknik analisis yang digunakan adalah analisis regresi linier berganda dengan tingkat signifikansi kepercayaan $\alpha=5 \%$. Hasil penelitian ini menunjukkan bahwa variabel profitabilitas yang diukur dengan proksi Return On Equity (ROE) berpengaruh positif terhadap kebijakan dividen. Sedangkan variabel leverage yang diukur dengan proksi Debt to Equity Ratio (DER) negatif tidak berpengaruh terhadap kebijakan dividen.
\end{abstract}




\section{PENDAHULUAN}

Perusahaan yang go public merupakan perusahaan yang para pemegang sahamnya terdiri dari berbagai berlatar belakang dari berbagai sisi, ada pemilik perusahaan mayoritas yang digambarkan dengan menanamkan kekayaannya dalam bentuk sahamnya dalam mayoritas dominasi jumlah yang besar, ada juga investor yang kecil, dan menengah, serta juga ada manajer yang mempunyai saham hak kepemilikan saham dalam perusahaan tersebut. Perusahaan yang diminati dan menjadi incaran oleh para investor adalah perusahaan yang profitabilitas meningkat dari tahun ke tahun. Dengan trend profitabilitas yang meningkat dan stabil akan memberikan tingkat keyakinan signal positif keluar dan diharapkan dapat memberikan keuntungan yang akan diterima oleh para pemegang saham ke depannya. Dan trend pembagian keuntungan yang diterima oleh para pemegang saham juga merupakan hal yang sangat penting juga

Peningkatan sisi profitabilitas perusahaan dan pembagian keuntungan kepada para pemegang saham ini sangatlah penting, akan tetapi terdapat fenomena bisnis dimana tingkat profitabilitas perusahaan dan pembagian keuntungan perusahaan yang diterima oleh para pemegang saham mengalami penurunan dari tahun 2015-2018.Ini dapat dilihat dari tabel 1 sebagai berikut :

Tabel 1 Rata-rata Kebijakan Dividen, Profitabilitas dan Leverage

\begin{tabular}{|c|r|r|c|}
\hline Tahun & \multicolumn{1}{c|}{ DPR } & \multicolumn{1}{c|}{ DER } & ROE \\
\hline $\mathbf{2 0 1 5}$ & 45.056 & 0.497 & 20.753 \\
\hline $\mathbf{2 0 1 6}$ & 5.713 & 0.599 & 22.282 \\
\hline $\mathbf{2 0 1 7}$ & 6.454 & 0.710 & 21.042 \\
\hline $\mathbf{2 0 1 8}$ & 7.167 & 0.861 & 16.431 \\
\hline
\end{tabular}

Sumber: data yang diolah tahun 2020

Pembagian keuntungan perusahaan kepada para pemegang saham, yang diwakili oleh proksi Dividen Payout Ratio
(DPR) mengalami penurunan dari tahun 2015 sebesar 45,056\% menjadi 7,167\% meski mengalami kenaikan dari5,713\% di tahun 2015 ke tahun 2018 sebesar $7,167 \%$. Tetapi secara overall pembagian kebijakan dividen ini mengalami penurunan dari tahun 2015 sampai dengan tahun 2018. Trend profitabilitas perusahaan yang diwakili oleh proksi Return On Equity (ROE) juga mengalami penurunan dari tahun 2015 sebesar $20,753 \%$ menjadi $16,431 \%$ di tahun 2018 .

Menurut Horne dan Wachowiz (2014) dividen adalah bagian dari laba perusahaan yang dibagikan kepada pemegang saham. Menurut Sutrisno (2013) dividen merupakan bagian keuntungan yang dibayarkan oleh perusahaan kepada para pemegang saham, sehingga dividen merupakan bagian penghasilan yang diharapkan oleh pemegang saham melalui kebijakan dividen. Harmono (2018) mendefinisikan kebijakan dividen adalah salah satu dari kebijakan penting manajemen keuangan perusahaan, juga merupakan persentase laba yang dibayarkan kepada para pemegang saham dalam bentuk dividen tunai, penjagaan stabilitas dividen dari waktu ke waktu, pembagian dividen saham dan treasury. Kebijakan dividen dapat diukur dengan beberapa aspek, salah satunya dengan rasio Dividen Payout Ratio (DPR) merupakan persentase laba yang dibayarkan kepada para pemegang

saham dengan rumusan dividen tunai dibagi dengan Earning Per Share (EPS)

Gumanti(2011). Profitabilitas adalah tingkat kemampuan perusahaan dalam memperoleh laba atau bisa diartikan tingkat kemampuan laba yang diwakili oleh proksi Return On Equity (ROE) dari hasil persentase perbandingan laba bersih sebelum pajak dengan total equity ( Brigham, 2010).

Leverage adalah momen ungkit dengan asumsi kondisi penjualan yang meningkat dan potensial, serta perusahaan 
mampu memanfaatkan momen tersebut untuk menghasilkan tingkat operasi yang efisien dan efektif dikaitkan dengan strategi pendanaan perusahaan. Rasio proksi yang dipakai untuk mewakili leverage adalah Debt to Equity Ratio (DER) yang persentase perbandingan antara total utang dengan total equity ( Prastowo, 2015)

Penelitian yang dilakukan oleh Sari dan Suryantini (2019), Jannati (2010), Nuringsih(2005), Awalina(2016) dan Rasyid, dkk(2015), Suharli (2007) yang menunjukkan bahwa profitabilitas berpengaruh positif dan signifikan terhadap kebijakan dividen. Sedangkan hal berbeda dengan hasil penelitian yang dilakukan oleh Dewi, (2008), Tariq,(2015) profitabilitas berpengaruh negatif signifikan terhadap kebijakan dividen, juga penelitian yang dilakukan oleh Ulfah , (2016) profitabilitas tidak berpengaruh terhadap kebijakan dividen. Profitabilitas yang tinggi akan memberikan lebih banyak porsi bagi perusahaan untuk membagikan penghasilan bagi pemegang saham melalui kebijakan dividennya dan ditangkap investor memberikan signal yang baik bagi investor. Disimpulkan bahwa profitabilitas berpengaruh terhadap kebijakan dividen.

\section{METODE}

Penelitian ini menggunakan pendekatan kuantitatif. Jenis data yang digunakan dalam penelitian ini adalah data sekunder. Data sekunder yang diperlukan adalah berupa ringkasan laporan keuangan perusahaan manufaktur tahun 2015-2018 yang diperoleh dari website www.idx.co.id. Teknik pengumpulan data sekunder adalah data yang diperoleh secara tidak langsung oleh pihak yang melaksanakan penelitian.

Populasi dalam penelitian ini adalah seluruh perusahaan manufaktur yang terdaftar di Bursa Efek Indonesia (BEI) pada tahun 2015-2018. Jumlah sampel ditentukan dengan menggunakan metode purposive sampling. Adapun kriteria sampel yang ditetapkan adalah perusahaan manufaktur yang terdaftar dan mempublikasikan laporan keuangan pada tahun 2015-2018 secara berturut-turut, perusahaan yang menerbitkan laporan keuangan dengan nilai mata uang rupiah, perusahaan yang membagikan dividen dan laba surplus selama 4 tahun berturut-turut sejak 2015-2018 dan perusahaan yang memiliki data lengkap terkait dengan variabel yang diteliti dalam penelitian ini.

Jumlah sampel dalam penelitian ini sebanyak 27 perusahaan atau 108 data selama empat tahun. Setelah melakukan

uji normalitas, terdapat beberapa data yang harus dihilangkan atau outlier, sehingga data yang digunakan menjadi 92 data.

\section{Teknik Analisis Data}

Teknik analisis data yang digunakan dalam penelitian ini adalah regresi linier berganda yang digunakan untuk menganalisis seberapa besar pengaruh variabel independen terhadap variabel dependen. Persamaan fungsi regresi linier berganda adalah sebagai berikut :

$\begin{array}{ll}\mathrm{Y}=\alpha+\beta 1 \mathrm{X} 1 & +\beta 2 \mathrm{X} 2+\mathrm{e} \\ \operatorname{dimana}: & \\ \mathrm{Y} & : \text { Kebijakan Dividen } \\ \mathrm{X} 1 & : \text { Profitabilitas } \\ \mathrm{X} 2 & : \text { Leverage } \\ \alpha & : \text { Konstanta } \\ \beta 1, \beta 2 & : \text { Koefisien } \\ \mathrm{e} & : \text { error }\end{array}$

\section{Pengukuran Variabel}

Variabel dependen dalam penelitian ini adalah kebijakan dividen yang diukur dengan rasio Dividen Payout Ratio (DPR). Variabel independen dalam penelitian ini adalah profitabilitas yang diukur dengan rasio Return On Equity (ROE), leverage yang diukur dengan rasio Debt to Equity Ratio (DER).

\section{HASIL DAN PEMBAHASAN}

Tabel 2 


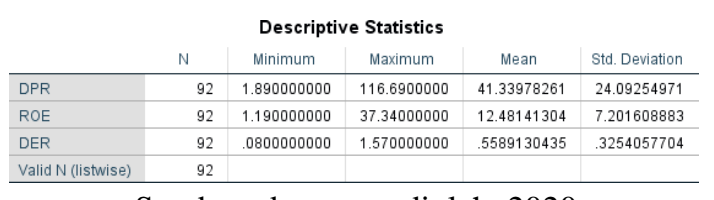

Sumber: data yang diolah, 2020

\section{Statistik Deskriptif}

Tabel 2 menyajikan laporan output SPSS mengenai deskripsi atau gambaran mengenai data tentang variabel independen yaitu profitabilitas yang diukur dengan rasio Return On Equity (ROE), leverage yang diukur dengan rasio Debt to Equity Ratio (DER) yang dilihat dari nilai rata-rata (mean), standar deviasi, minimum dan maksimum. Jumlah sampel sebanyak 92 data. Nilai Return On Equity (ROE) mempunyai nilai mean sebesar 12,48141, standar deviasi sebesar 7,21060 , nilai minimum sebesar 1,19000 dan nilai maksimum sebesar 37,34000 . Nilai Debt to Equity Ratio (DER) mempunyai nilai mean sebesar 0,5589130, standar deviasi sebesar 0,3254057 , nilai minimum sebesar 0,08000 dan nilai maksimum sebesar 1,57000. Variabel dependen dalam penelitian ini adalah Dividen Payout Ratio (DPR) mempunyai nilai mean sebesar 41,33978, standar deviasi 24,09254, nilai minimum sebesar 1,89000 dan nilai maksimum sebesar 116,69000 .

\section{Uji Normalitas}

Uji normalitas digunakan untuk melihat apakah suatu data telah terdistribusi normal atau tidak sebelum dilakukan uji regresi linier. Ada dua cara untuk mendeteksi apakah residual berdistribusi normal atau tidak yaitu dengan analisis grafik dan uji statistik (Ghozali, 2013). Analisis grafik dengan melihat hasil output SPSS grafik histogram dan Normal $P$ Plot of Regression Standarized Residual.Berikut hasil uji normalitas dengan melihat dari grafik histogram dan Normal P Plot of Regression Standarized Residual :

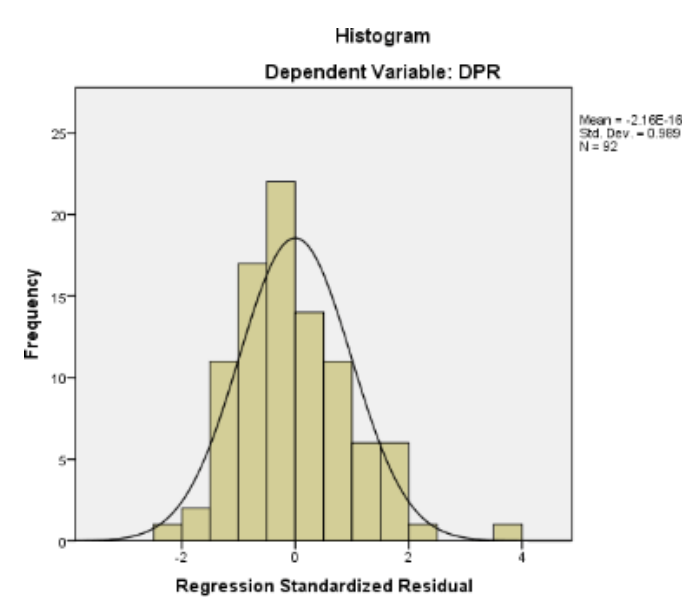

Gambar 1. Hasil Uji Normalitas Grafik Histogram.

Gambar 1 menunjukkan bahwa grafik histogram menunjukkan pola berdistribusi normal.

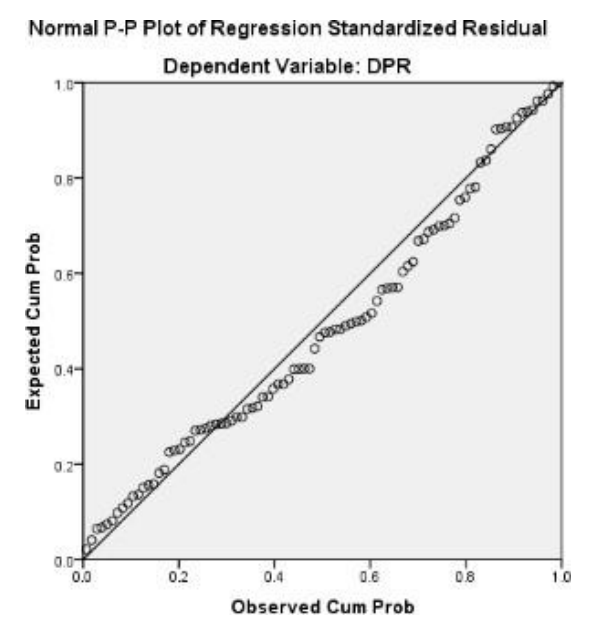

Gambar 2.Hasil Uji Normal P Plot of Regression Standarized Residual

Gambar 2 menunjukkan bahwa titik-titik menyebar sekitar garis diagonal dan penyebarannya mengikuti arah garis diagonal, maka model regresi layak dipakai, karena telah memenuhi asumsi normalitas.

Tabel 3. Hasil Uji Normalitas dengan uji statistik 


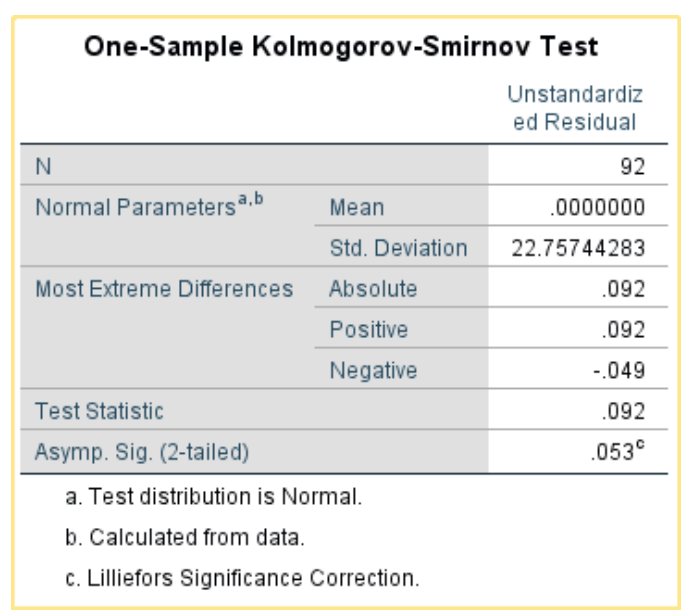

Sumber : data yang diolah, 2020

Pengujian secara statistik sebagaimana ditampilkan pada tabel 3, dapat dilihat dari nilai signifikan variabel, jika nilai signifikan variabel > 0,05 maka data dianggap normal . Dalam penelitian ini nilai signifikan variabel berada diatas 0,05 yang mana berarti data tersebut sudah memenuhi data terdistribusi normal.

\section{Uji Multikolineritas}

Uji multikolineritas digunakan untuk melihat apakah dalam model regresi terdapat korelasi antar variabel independennya. Untuk mendeteksi ada tidaknya multikolineritas dapat dilakukan dengan cara melihat nilai tolerance dan Variance Inflation Factor (VIF). Hasil pengujian Uji Multikolineritas dapat dilihat pada tabel 4 berikut ini :

Tabel 4. Uji Multikolineritas

\begin{tabular}{|c|c|c|c|c|c|c|c|c|}
\hline \multicolumn{9}{|c|}{ Coefficients ${ }^{\mathrm{a}}$} \\
\hline \multirow[b]{2}{*}{ Model } & & \multicolumn{2}{|c|}{ Unstandardized Coefficients } & \multirow{2}{*}{$\begin{array}{c}\text { Standardized } \\
\text { Coefficients } \\
\text { Beta }\end{array}$} & \multirow[b]{2}{*}{$t$} & \multirow[b]{2}{*}{ Sig. } & \multicolumn{2}{|c|}{ Collinearity Statistics } \\
\hline & & B & Sttd. Erôr & & & & Tölèrancé & VIF \\
\hline 1 & (Constant) & 35.159 & 6.837 & & 5.142 & .000 & & \\
\hline & DER & $=9.866$ & 7.504 & :133 & $\cdot 1.315$ & 192 & .976 & 1.025 \\
\hline & ROE & .937 & .339 & .280 & 2.764 & .007 & 976 & 1.025 \\
\hline
\end{tabular}

Sumber: data yang diolah, 2020.

Suatu data dikatakan tidak mengalami multikolineritas apabila nilai tolerance > 0,10 dan nilai VIF $<10$ maka dapat dikatakan bahwa model dalam penelitian bebas dari multikolineritas. Output SPSS diatas memperlihatkan bahwa nilai tolerance dari nilai variabel ROE dan
DER $>0,10$ dan nilai VIF $<10$, sehingga dapat dikatakan bahwa model dalam penelitian ini bebas dari adanya multikolineritas.

\section{Uji Heteroskedastisitas}

Uji heteroskedastisitas bertujuan untuk menguji apakah dalam model regresi terjadi ketidaksamaan variance dari residual satu pengamatan ke pengamatan yang lain. Jika variabel independen signfikan secara statistik mempengaruhi variabel dependen maka ada indikasi terjadi heteroskedastisitas (Ghozali, 2013). Berdasarkan hasil pengujian dengan menggunakan uji glesjer terlihat bahwa tingkat koefisien signifikansi >0,05 sehingga dapat dikatakan bahwa model tidak terdapat heteroskedastisitas. Hasil uji heteroskedastisistas dapat dilihat pada tabel 5 sebagai berikut :

Tabel 5 Uji Heteroskedastisitas Coefficients $^{\mathrm{a}}$

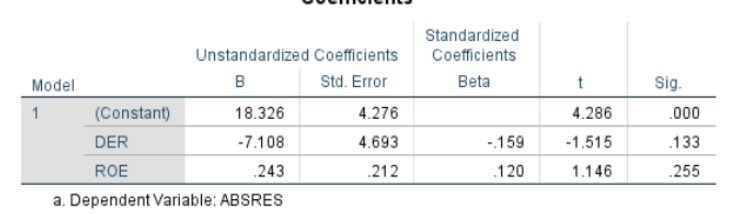

Sumber : data yang diolah, 2020

\section{Uji Autokorelasi}

Autokorelasi adalah hubungan yang terjadi antara residual dari pengamatan satu dengan pengamatan lain. Model regresi yang baik adalah yang tidak terjadi autokorelasi. Uji autokorelasi yang digunakan dalam penelitian ini adalah Durbin Watson. Hasil uji autokorelasi dapat dilihat pada tabel 6 berikut ini : Tabel 6 Uji Autokorelasi Durbin Watson

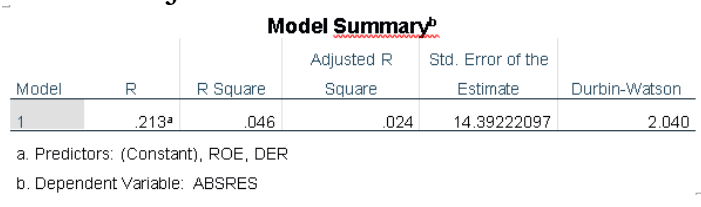

Berdasarkan tabel 6 diatas diketahui nilai DW sebesar 2.040, nilai dU pada tabel sebesar 1.7053, nilai dL pada tabel sebesar 1.6166, sehingga nilai 4-dU adalah sebesar 
2.2947. Apabila nilai dU < d < 4-dU, maka tidak ada autokorelasi positif atau negatif yang berarti tidak terdapat autokorelasi. Berdasarkan hasil uji autokorelasi diatas dapat disimpulkan bahwa $1.7053<2.040$ $<2.2947$, maka dapat disimpulkan bahwa tidak terdapat autokorelasi.

\section{Uji Model}

Bertujuan untuk mengukur besarnya presentasi pengaruh variabel independen terhadap variabel dependen. Hasil pengujian koefisien determinasi dapat dilihat pada tabel 7 berikut ini:

Tabel 7 Hasil Uji Koefisien

Determinasi

\begin{tabular}{|c|c|c|c|c|}
\hline \multirow[b]{2}{*}{ Model } & \multicolumn{3}{|c|}{ Model Summary ${ }^{\mathbf{b}}$} & \multirow[b]{2}{*}{$\begin{array}{l}\text { Std. Error of } \\
\text { the Estimate }\end{array}$} \\
\hline & $\mathrm{R}$ & $R$ Square & $\begin{array}{l}\text { Adjusted R } \\
\text { Square }\end{array}$ & \\
\hline 1 & $.328^{\mathrm{a}}$ & .108 & .088 & 23.01172383 \\
\hline
\end{tabular}

Sumber : data yang diolah, 2020

Hasil output SPSS pada tabel 7 menunjukkan bahwa nilai Adjusted $\mathrm{R}$ Square sebesar 0,088 . Hal ini berarti kebijakan dividen dapat dijelaskan oleh variabel profitabilitas dan leverage sebesar $8.8 \%$. Sementara sekitar $91.2 \%$ dijelaskan oleh variabel lain yang tidak dikategorikan dalam model.

\section{Pengujian Hipotesis}

Hasil pengujian hipotesis pada tabel 8 dengan menggunakan uji $\mathrm{t}$ statistik dilakukan untuk menguji pengaruh dari masing-masing variabel independen terhadap variabel dependen. Apabila nilai sig $\mathrm{t}<$ tingkat signifikansi ( 0.05) maka hipotesis diterima, sedangkan apabila nilai sig $\mathrm{t}>$ tingkat signifikansi (0.05) maka hipotesis ditolak.

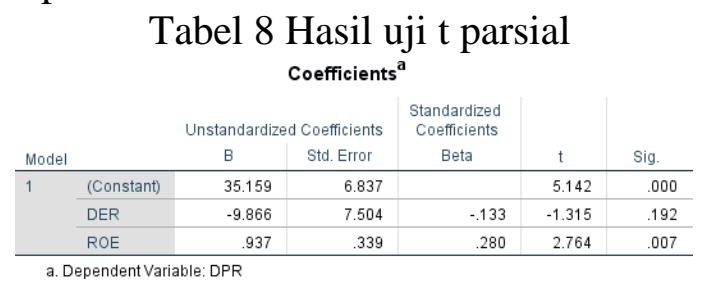

Sumber : data yang diolah, 2020
Hasil pengujian hipotesis tersebut menghasilkan persamaan analisis linier regresi berganda berikut ini :

Kebijakan Dividen $=35.159+0,937$ Profitabilitas - 9,866 Leverage $+\mathrm{e}$

Hipotesis ke satu menguji pengaruh profitabilitas yang diukur dengan rasio Return On Equity (ROE) terhadap kebijakan dividen (DPR). Berdasarkan hasil pada tabel 8 diatas memperoleh nilai t hitung sig 0,007 < 0.05 , yang berarti bahwa hipotesis ke satu diterima. Hasil penelitian ini konsisten dengan penelitian yang dilakukan oleh Jannati (2010), Rasyid (2015), Suryantini (2019), dan Awalina (2016). Bahwa probabilitas semakin tinggi akan membuat perusahaan semakin besar membagikan dividen.

Hipotesis kedua menguji pengaruh leverage yang diukur dengan rasio Debt to Equity Ratio (DER) terhadap Kebijakan Dividen (DPR). Berdasarkan hasil pada tabel 7 diatas memperoleh nilai thitung sig $0,192>0,05$ yang berarti bahwa hipotesis kedua dinyatakan ditolak. Keputusan leverage tidak mampu memberikan pengaruh meningkatkan tingkat proporsi pembagian dividen tunai kepada para pemegang saham. Hasil penelitian ini konsisten dengan penelitian yang dilakukan oleh Utami dan Robin (2015), bahwa leverage tidak signifikan terhadap kebijkan dividen.

\section{SIMPULAN DAN SARAN}

Hasil penelitian ini menunjukkan bahwa variabel profitabilitas dengan rasio Return On Equity (ROE) berpengaruh terhadap kebijakan dividen ditunjukkan dengan uji t statistik menghasilkan 2,764 untuk variabel profitabilitas dengan $\mathrm{t}$ signifikan $0,007<0,005$. Sedangkan variabel leverage yang diukur dengan rasio Debt to Equity Ratio (DER) negatif 
tidak berpengaruh terhadap kebijakan dividen, ditunjukkan dengan uji t statistik menghasilkan nilai $-1,315$ dengan $\mathrm{t}$ signifikan $0,192>0,05$. Saran bagi peneliti yang akan datang diharapkan

\section{DAFTAR PUSTAKA}

Afriyeni, dan Deas,K, 2019. Pengaruh Profitabilitas, Leverage, Growth Terhadap Kebijakan Dividen, Jurnal Benefita, vol 4 (3) Oktober 2019. (399-411)

Awalina, Putri. 2016. Pengaruh Struktur Kepemilikan, Free Cash flow, dan Return On Asset Terhadap Dividend Payout Ratio. Cendikia Akuntansi.Vol. 4, No. 1.

Ang, Robert, 1997. Buku Pintar Pasar Modal Indonesia. Mediasoft Indonesia, Jakarta

Atmaja. Lukas, 2008. Manajemen Keuangan Edisi Revisi. Penerbit Andi, Yogyakarta

Brigham, Eugene, and Gapenski, 1996. Intermediate Financial Management, The Dryden Press., Florida

Brigham, Eugene, and Houston J.F., 2007. Fundamentals of Financial. Management, Eleventh Edition, Thomson South-Western, United States of America.

Brigham, Eugene, and Houston, 2010. Dasar-dasar Manajemen Keuangan, Edisi 11 buku 1., Salemba Empat, Jakarta.

Chariri, A., and Ghazali, I., 2003. Teori Akuntansi. Badan Penerbit Universitas Dipenogoro, Semarang.

Dewi, Sisca Christianty, 2008. Pengaruh Kepemilikan Managerial, Kepemilikan Institusional, Kebijakan Hutang, Profitabilitas dan Ukuran Perusahaan Terhadap Kebijakan Dividen, Jurnal Bisnis dan Akuntansi. Vol 10 No 1, 47-58.

Dwi, P., 2015. Analisis Laporan Keuangan Konsep dan Aplikasi, UPP STIM YKPN., Yogyakarta.

Gitman, Lawrence J. 2006. Essentials of Managerial Finance. Fourth Edition. Pearson Education. Inc, United States

Ghozali, I., 2011. Aplikasi Analisis Multivariate dengan Program SPSS. Badan Penerbit UNDIP. Semarang

2004. Model Persamaan Struktural Konsep Aplikasi Dengan Program AMOS 16. Badan Penerbit UNDIP, Semarang.

Guinan, 2009. Investopedia. Mizan Publika, Jakarta

Gumanti, dan Tatang, 2011. Manajemen Investasi Konsep, Teori dan Aplikasi. Mitra Wacana Media, Jakarta

Harmono, 2014. Manajemen Keuangan Berbasic Balanced ScoreCard, Bumi Aksara, Jakarta

Harmono, 2018. Manajemen Keuangan Berbasis Balanced Scoredcard Pendekatan Teori, Kasus dan Riset Bisnis, Bumi Aksara. Jakarta

Hartono, Jogiyanto., 2009. Teori Portofolio dan Analisis Investasi. Edisi Keenam. Yogyakarta: BPFEYogyakarta. untuk menambah variabel rasio keuangan dan bisa mengamati sektor perusahaan di Bursa Efek Indonesia selain perusahaan manufaktur.
Hasibuan, Veronica, and Dzulkirom, M. and Endang, N.G, 2016, Pengaruh Leverage dan Profitabilitas Terhadap Nilai Perusahaan, Jurnal Administrasi Bisnis (JAB), no 1, 139-147

Horne, Varne , and James, C., 2002. Financial Management and Policy, $12^{\text {th }}$, Fundamentals of Financial Management, $12^{\text {th }}$, Prentice-Hall

Horne, Varne, and Wachowicz, 2008. Fundamentals of Financial Management, $13^{\text {th }}$, Prentice-Hall.

Husnan, Suad, 1996. Manajemen Keuangan Teori Dan Penerapan (Keputusan Jangka Panjang ). Edisi 4, BPFE, Yogyakarta.

Jannati, 2010, Pengaruh Profitabilitas, Leverage , Dan Growth Terhadap Kebijakan Dividen,Jurnal Ekonomi Bisnis, Universitas Siliwangi

Kasmir, 2016. Analisis Laporan Keuangan. Cetakan ketujuh. Jakarta: PT Raja Grafindo Persada

Keown, A.J., 2003. Manajemen Keuangan : PrinsipPrinsip dan Aplikasi. Jakarta : PT. Indeks Kelompok Gramedia.

Lioew, Alfian.2014, ROA, ROE, NPM Pengaruhnya Terhadap Dividen Payout Ratio, Jurnal EMBA, vol 2 no $2,1406-1416$

Martono, dan Harjito, 2012. Manajemen Keuangan. Ekonosia, Yogyakarta

Nuringsih, 2005. Analisa Pengaruh Kepemilikan Manajerial, Kebijakan Utang, ROA, Dan Ukuran Perusahaan Terhadap Kebijakan Dividen: Studi 1995-1996, Jurnal Akuntansi dan Keuangan Indonesia. Vol 2 No 2, 103-123.

Prastowo, Dwi, 2015. Analisa Laporan Keuangan. UPP STIM YKPN, Yogyakarta.

Prihadi, Toto, 2012. Analisis Laporan Keuangan. PPM, Jakarta

Rasyid, A., and Mahfudnurjamuddin and Mas'ud, and Suun, M., 2015. Effect of Ownership Structure, Company Size and Profitability on Dividend Policy and Manufacturing Company's value in Indonesia Stock Exchange, Australian Journal of Basic and Applied Sciences, 2015, 9(20), 618-624

Ross, and Westerfield, 2009. "Essentials of Corporate Finance”, McGraw Hill Inc. Boston

Sartono, A., 2012. Manajemen Keuangan Teori dan Aplikasi, Edisi 4. Yogyakarta: BPFE 2014. Manajemen Keuangan, Teori dan Aplikasi. Yogyakarta: BPFE

Sudana, I.M. 2011. Manajemen Keuangan Perusahaan Teori dan Praktek. Erlangga, Jakarta.

Suharli. 2007. Pengaruh Profitability dan Investment Opportunity Set Terhadap Kebijakan Deviden Tunai dengan Likuiditas Sebagai Variabel Penguat, Jurnal Akuntansi Dan Keuangan, vol. 9, no. 1, mei 2007: 9-17. 
Suryantini,N.P.S, dan Saraswati,A.P, 2019 Pengaruh Leverage, Firm Size, Profitabilitas Terhadap Kebijakan Dividen Pada Perusahaan Manufaktur, E-Jurnal Manajemen, Vol. 8, No. 7, 2019 :45594588

Suwardjono, 2005. Teori Akuntansi: Perekayasaan Pelaporan Keuangan, Edisi Ketiga, BPFE Yogyakarta

Tariq, A. 2015. The joint determinants of leverage And dividend policy: a balanced panel Study of non financial firms of india and Pakistan. European Scientific Journal. April 2015 edition vol.11, No.10 ISSN: 185727881 (Print) e - ISSN 18577431.

Udayani, Dewi, dan Suaryana, I.G., 2013. Pengaruh Probabilitas Dan Investment Opportunity Set Pada Struktur Modal, E-Jurnal Akuntansi Universitas Udayana, vol 4 (2), 299-314.

Ukhriyawati, Catur, dan Malia, R., 2018, Pengaruh Profitabilitas, Keputusan Investasi dan Kebijakan Hutang Terhadap Nilai Perusahaan, Jurnal Bening Universitas Riau, vol 5 no 1, 14-26

Ulfah, Azmia. 2016. Faktor-Faktor Yang Mempengaruhi Kebijakan Dividen dan Dampak Kebijakan Dividen Terhadap Struktur Modal Bank BUMN Periode 2005-2014. Perbanas Institute Journals, 2 (1): $1-16$

Usunariah, 2003. Pengantar Pasar Modal. UPP MPP YKPN, Yogyakarta
Utami, Gayatri Kurnia dan Robin, 2015. Analisis FaktorFaktor Yang Mempengaruhi Rasio Pembayaran Dividen Pada Perusahaan Yang Terdaftar Di Bursa Efek Indonesia, Jurnal Manajemen, vol 15 no 1, November 2015, 41-58

Warsono, 2003. Manajemen Keuangan Perusahaan. Jilid 1. Bayu Media Publishing, Malang.

Weston, and Copeland, 1995. Financial Theory and Corporate Policy, $5^{\text {rd }}$ edition, Addison-Wesley Publishing Company.

Weston, and Copeland, 2010. Manajemen Keuangan. Jakarta, Salemba Empat 